\title{
Uma engrenagem que move o ler e o escrever
}

\author{
Leila Conceição Rosa dos Santos, D.Sc. ${ }^{*}$
}

Sempre que surge o convite para um editorial, a primeira reação é de prazer. Uma vez ciente do conteúdo da revista, começam as conexóes entre o conhecimento que aquele conteúdo pretende trazer e a minha prática profissional. Naturalmente uma teia de pensamentos começa a ser formada e o pano de fundo está praticamente pronto; contudo, o desafio é o seguinte: Como colocar tudo isso para o leitor? Afinal, quem é o leitor de uma revista científica? Qual foi a porta de entrada dele neste periódico em especial? Teria ele buscado um tema específico em banco de dados? Estaria ele fazendo uma pesquisa prazerosa na aquisição de um novo conhecimento para transformar sua prática ou, num momento de intensa pressão, para elaborar um trabalho de conclusão de curso? Situações como estas são as que encontro onde tenho atuado constatando o potencial avanço de nossos alunos de pós-graduação no questionamento de suas práticas e na delimitaçáo de seus problemas de estudo. Além disso, necessário se faz acompanhar as dificuldades e o sofrimento que isso traz para alguns estudantes que nos chegam sem preparo e/ou tradição de pesquisa.

O que me leva a tantas questóes num editorial? Iniciar pelo que atinge o outro numa relação, mesmo que feita aqui de forma escrita e tratá-lo como pessoa, procurando, assim, entendê-lo dentro de seu contexto. Daí, sim, estabelecida uma relação de empatia (ainda que incipiente) as questóes importantes que serão expressas neste número, através dos artigos com temáticas que abrangem saúde mental e reabilitação, dentre outros, trarão o sentido que se pretende, ou seja, contribuir na construçáo de uma Enfermagem que, a partir do humano, está alicerçada em bases sólidas e conscientes da busca pela excelência.

Dessa forma, pessoas (leitores) respeitadas na sua individualidade, dentro de seus contextos, exercendo uma profissáo que leva em conta o cenário mundial que nos mostra como palavra de ordem "mudanças" (sociais, econômicas, políticas e culturais), se encontrarão aqui com outras (autores), que estudaram, pesquisaram, escreveram e agora dividem conosco o que aprenderam. Que isso, de alguma forma e em algum nível de profundidade, seja incentivado a ser feito em suas práticas que entrelaçam conhecimento, pensamento e ação.

Daí, caminho para o que pretendi tecer, isto é, que parte da engrenagem necessária para o grande processo de construçáo desse cuidar clínico, tecnológico e educacional em que estamos envolvidos possa ser um incentivo para o aumento do conhecimento e para a divulgaçáo dos seus resultados. Essa é a figura que produz a ação e que nos move pessoal e profissionalmente.

Assim, para o leitor que iniciou sua leitura através deste editorial, nossas boas vindas a uma pequena parte de um mundo de conhecimentos a serem (re)descobertos, (re)construídos, (re) editados... 